\title{
Innovative expansion of a large centreline constructed tailings storage facility in a seismically-active area
}

\author{
K.F. Morrison Golder Associates Inc., United States of America \\ J.M. Johnson Golder Associates Inc., United States of America \\ A.J. Augello Golder Associates Inc., United States of America \\ B. Doughty Thompson Creek Metals, United States of America
}

\begin{abstract}
The Bruno Creek Tailings Impoundment, located in seismically-active central Idaho, United States of America, retains tailings behind one of the tallest centreline-raise cyclone tailings sand dams in the world. From a current height of approximately $170 \mathrm{~m}$, the dam is proposed to be raised to a height of nearly $230 \mathrm{~m}$ based on projected life of mine (LOM) ore reserves. An alternatives evaluation indicated the preferred option for tailings expansion is to raise the existing facility using the centreline raise method over most of the dam alignment, but modifying the design to employ a partial realignment of the dam crest at the left abutment. This change will result in a length of the previously centreline-raised dam being constructed over an existing tailings beach. The design also includes steepening of the downstream dam slopes, as well as construction of a raise on the existing rock toe dam to limit downstream impacts. This paper presents the geotechnical design aspects of the project, focusing on the site seismicity and assessment of dynamic liquefaction potential.
\end{abstract}

\section{Introduction}

The Thompson Creek Mine (TCM) is a molybdenum mine located in Custer County, Idaho, USA. Since 1983, TCM has mined molybdenum ore from an open pit, which is milled into molybdenum concentrates for transportation offsite and subsequent processing.

Mine tailings produced at TCM are stored in the Bruno Creek catchment using a cycloned sand dam and centreline-raise technique (Figure 1). In this type of operation, the tailings are split into a coarse and fine fraction using a series of cyclones. The coarser tailings fraction is directed to form the outer, confining shell of the dam, while the finer fraction of material is directed to be retained within the basin of the facility. Tailings are piped as 35 to 40 percent solids by weight slurry from the mill to the tailings impoundment and either cycloned to separate sand for dam construction (with slimes deposited into the impoundment) or directly deposited into the impoundment (as whole tailings) from perimeter discharge points. Current operations include cyclone construction of the tailings dam for approximately six months each year with a total of approximately 24 percent of the tailings stream consisting of sand for dam construction.

Operation of the tailings impoundment at the TCM commenced in August 1983. With the exception of temporary shutdowns in 1991 and from December 1992 to March 1994, the tailings impoundment has been in continuous operation (SRK, 1995). At the time of this study, the sand dam was approximately $170 \mathrm{~m}$ high and retained approximately 136 million tonnes $(\mathrm{Mt})$ of tailings, which includes the tailings sand used to construct the dam. The facility was formerly designed and permitted to contain up to $180 \mathrm{Mt}$ of tailings (through Phase VII), and be constructed to an elevation of approximately 2,330 $\mathrm{m}$ (200 $\mathrm{m}$ high) above mean sea level (amsl). This study included development of the life of mine (LOM) design and permitting for the facility, which incorporated an additional $90 \mathrm{Mt}$ of tailings, bringing the storage capacity of the ultimate facility to approximately $270 \mathrm{Mt}$. 


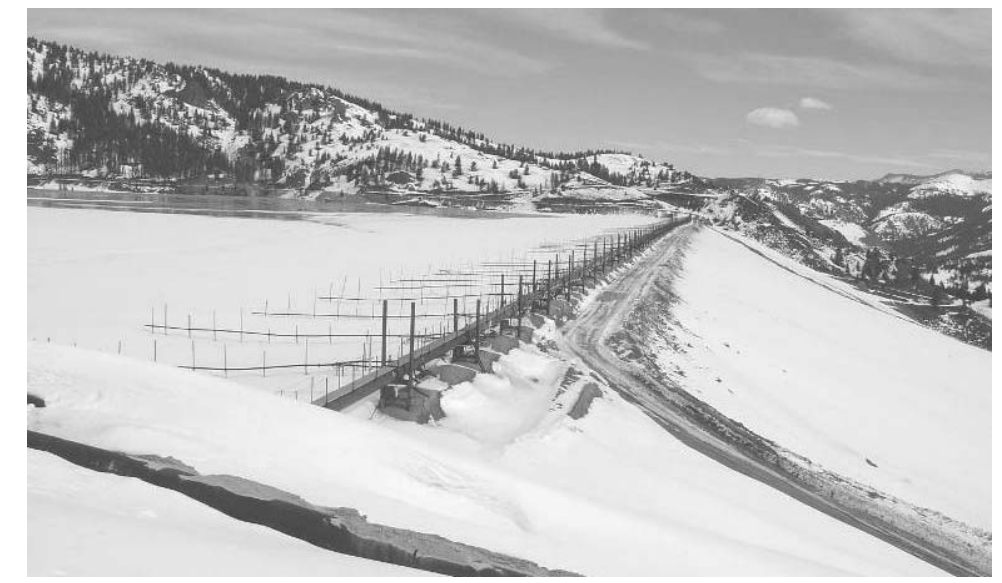

\section{Figure 1 Cyclone sand dam construction}

\section{Expansion design concept and development}

An alternative evaluation was conducted which indicated that the proposed LOM expansion (i.e. approximately $90 \mathrm{Mt}$ ) could not be stored within the existing Bruno Creek Tailings Impoundment without making modifications to the existing embankment configuration. Otherwise, an alternative storage facility would need to be considered. The selected alternative consisted of realigning the crest of the centreline-raise sand dam at the left abutment to contact the ridgeline further upstream, which enables raising of the embankment without overtopping the ridgeline. This alternative was selected because it allowed for the anticipated tailings through the LOM to be stored in one location, eliminating the need to develop a new tailings impoundment downstream or within another site catchment. Also, numerous past geotechnical, geological, and hydrological studies in the Bruno Creek drainage area could be used to reduce the required scope of new studies.

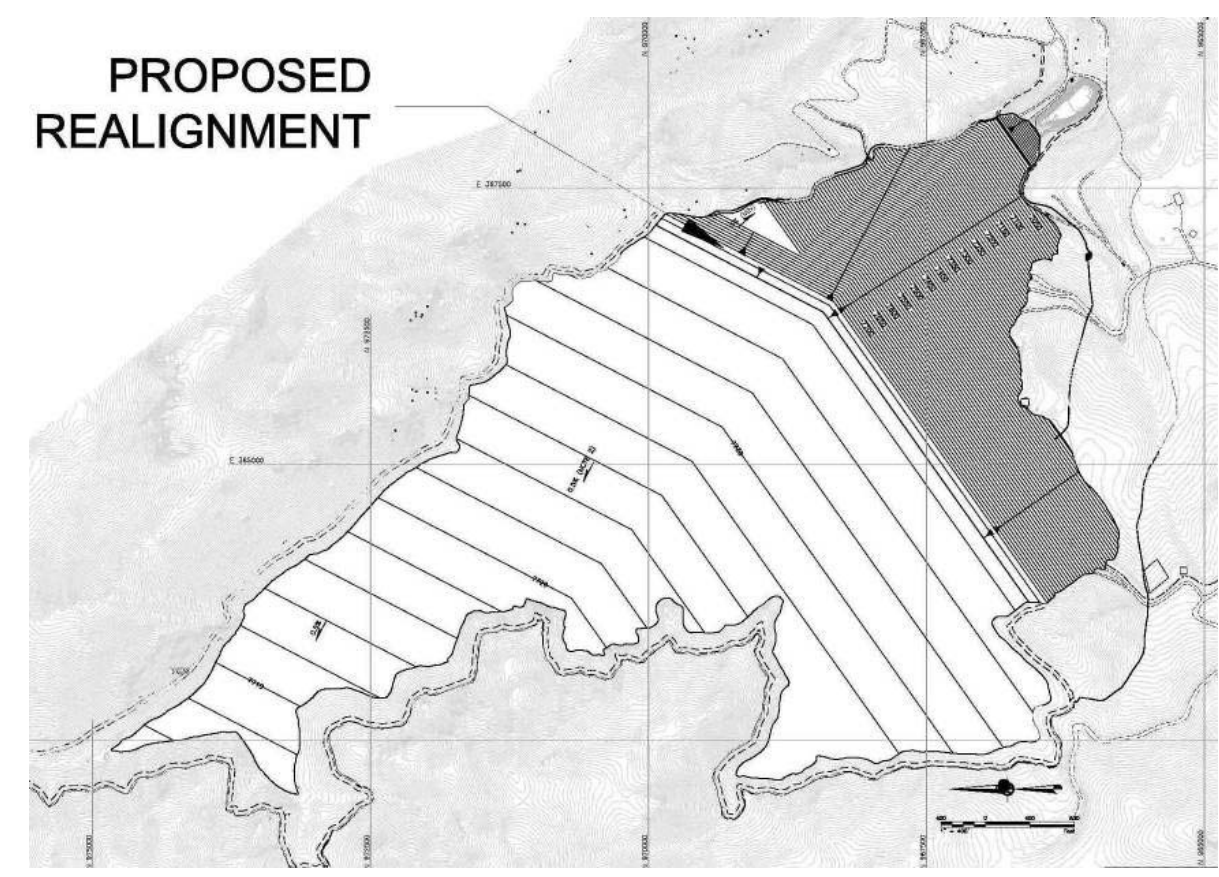

\section{Figure 2 Proposed ultimate embankment configuration}

The selected concept includes construction of a raise on the existing Bruno Creek Tailings Dam to an approximate elevation of 2,360 m amsl, which is $30 \mathrm{~m}$ higher than the previously-designed facility (through Phase VII). The raise will include realignment of the dam centreline with construction of a starter dike near the left abutment, as controlled by topography (i.e. the existing left abutment elevations are too low to 
accommodate the LOM raise), and continued construction of the existing centreline raise dam along the remainder of the alignment. The concept is illustrated in Figure 2.

To limit downstream impacts as well as reduce the volume of sand required for dam construction, a steepened downstream dam slope of $2.75 \mathrm{H}: 1 \mathrm{~V}$ (horizontal:vertical) is proposed for the structure, from the former $3 \mathrm{H}: 1 \mathrm{~V}$ downstream slope. The proposed slope inclination is controlled by stability considerations. To further limit downstream impacts, a downstream raise on the existing rock toe dam is proposed.

\section{Seismicity}

\subsection{Geologic setting}

The TCM site is located near the boundary of the Idaho Batholith of the Rocky Mountains and northern part of the Basin and Range province within central Idaho, United States. The Basin and Range province is characterised by a distinctively alternating pattern of fault-bounded, linear, generally north-south-trending hills and mountains separated by deep, sediment-filled valleys. The province is bounded on the east by the Colorado Plateau, the Columbia and Snake River Plateaus to the north, and the Sierra Nevada to the west. The province extends southward through Nevada, eastern California, and southern Arizona into northern Mexico. Rocks exposed within this region of the Basin and Range are typically Precambrian (more than 600 million years ago) metamorphic rocks, Phanerozoic (between about 70 and 600 million years ago) intrusive and sedimentary rocks, and younger volcanic rocks that erupted during the development of the Basin and Range Province during about the last 30 million years.

\subsection{Historic seismicity}

Historical earthquake records reveal that the TCM project area is located within a seismically-active area, and has been subject to moderate to strong earthquake shaking in at least the last 100 years. Instrumental records from the early twentieth century to March 2007 (time of the study) reveal that at least 130 earthquakes of magnitude $M \geq 4.0$ have been recorded within about $100 \mathrm{~km}$ of the mine site (Figure 3). The largest earthquake recorded close to the TCM site was the M 6.81 Borah Peak earthquake (approximately $60 \mathrm{~km}$ southeast of the site) that occurred on 28 October 1983 (Richins et al., 1987), shortly after construction and during the early filling stages of the tailings impoundment.

\subsection{Selection of seismic design parameters}

Rule 45 of the Idaho Administrative Code (IAC, 2010a) (Mines Tailings Impoundment Structure Rules) states that:

“... construction by the upstream method shall not be used in the area of the state east of Range 22 E, Boise Meridian, unless the engineer can provide evidence that the construction and operation of the tailings impoundment will achieve a relative density of sixty percent (60\%) or greater in the embankment and tailings to prevent liquefaction during earthquake loading."

The moderate to high seismic activity of the TCM area provided basis for seismic design of the facility, particularly with regard to the crest realignment portion of the proposed ultimate facility.

In accordance with the Idaho Administrative Code (IAC, 2010b) Safety of Dam Rules, seismic design of an intermediate or large dam must be evaluated for "the maximum ground motion/acceleration generated by the maximum credible earthquake." The Idaho code, however, does not provide guidance on selecting the maximum ground motion. A two-level seismic design approach was recommended for the site. For operational dynamic stability analyses, design should be accomplished for the ground motion from the Operational Basis Earthquake (OBE). For long-term post-closure dynamic stability analyses, the ground motion from the Maximum Credible Earthquake (MCE) was recommended for design. 


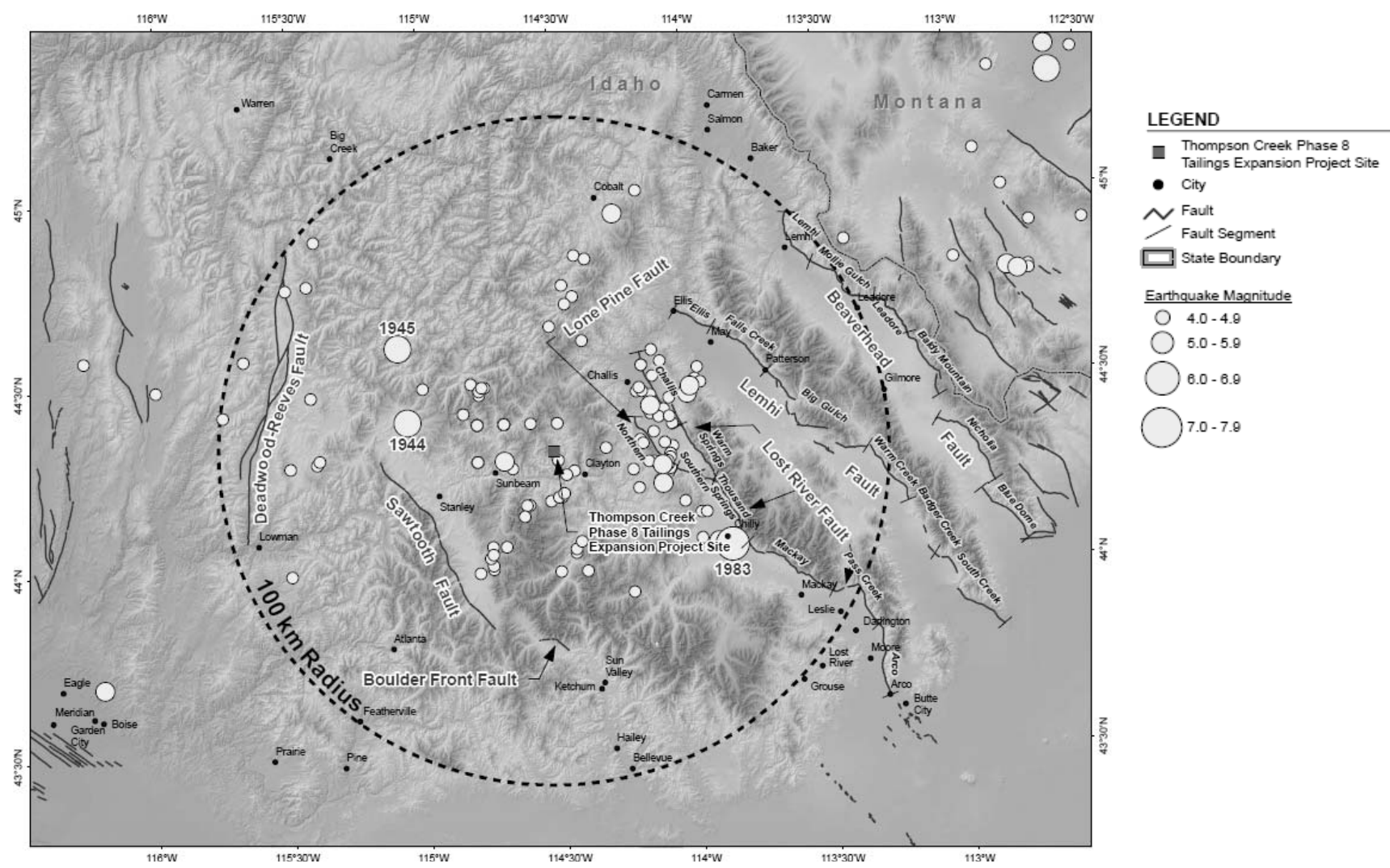

Figure 3 Seismic epicentres and earthquake magnitudes within $100 \mathrm{~km}$ of site

ICOLD (2002) states that "the dam, appurtenant structures and equipment should remain functional and damage easily repairable after the occurrence of an OBE." For a critical structure, such as TCM's Bruno Creek Tailings Impoundment, ICOLD (2002) further states that "the design should provide a structure able to safely withstand the maximum design earthquake (MDE)...able to operate and make releases to protect the dam against failure." For the Bruno Creek Tailings Impoundment, the controlling MCE represents the MDE in the ICOLD design criteria.

The controlling MCE is a background M 6.5 earthquake located approximately $10 \mathrm{~km}$ from the TCM site. The median plus one standard deviation ground motion generated at the site from the MCE is $0.3 \mathrm{~g}$ and has a return period of approximately 5,000 years. This peak ground acceleration (PGA) was used for both the operational maximum design event (MDE) dynamic stability analyses and the post-closure analyses.

For operational OBE dynamic stability analyses, the design earthquake is an M 5.8 earthquake located approximately $22 \mathrm{~km}$ from the site. The OBE PGA at the site is $0.12 \mathrm{~g}$ with a return period of approximately 475 years.

\section{$4 \quad$ Field testing programme}

A geotechnical investigation was conducted to evaluate the subsurface conditions present within the tailings dam and proposed LOM expansion areas. Specifically, investigations were performed along the existing dam centreline and proposed LOM crest realignment, at the left and right abutments, at the dam toe, and within identified construction borrow areas. The new information was used to supplement data from geotechnical investigations performed prior to dam construction, as well as other investigations performed during the course of the past nearly 30 years of operation of the facility. The field investigation programme consisted of eight cone penetration test (CPT) soundings, ten boreholes, and a series of test pits. The cone penetration testing programme is discussed in the next section. 


\subsection{Cone penetration testing}

Eight CPT soundings were conducted into the Bruno Creek Tailings Impoundment, including three along the existing dam centreline and five along the proposed crest realignment (refer to Figure 2), each sounding advanced to a depth of approximately $60 \mathrm{~m}$ below ground surface, unless cone refusal was met prior to reaching the $60 \mathrm{~m}$ depth. The $60 \mathrm{~m}$ depth was selected primarily to assess the foundation for design of the proposed realignment, as the proposed ultimate height of this spur dike would be approximately $60 \mathrm{~m}$ above the existing tailings beach (and approximately $30 \mathrm{~m}$ above the tailings beach at the time of crest realignment). Cone refusal was met in three of the CPT soundings at the contact between tailings and native foundation materials.

Two of the CPT soundings advanced along the proposed crest realignment were paired with conventional boreholes to assist development of site-specific correlations between the CPT soundings, tailings materials, and standard penetration test (SPT) blow counts. Within these paired boreholes, geotechnical samples in the form of Shelby tube, modified California barrel sampler, or SPT split spoon sampler was performed at $3 \mathrm{~m}$ intervals while drilling.

Jeffries and Davies (1993) present an equation to calculate SPT $N_{60}$ values (i.e. SPT blow counts corrected for energy only) from the normalised cone tip resistance and normalised friction ratio obtained during CPT soundings. This equation was developed from the results of calibration chamber testing and a limited number of site investigations performed by the authors (Jeffries and Davies, 1993). Figure 4 presents results from one CPT advanced along the proposed crest realignment, which was paired with a borehole. This figure shows a good correlation between the calculated SPT $N_{60}$ values using the CPT and the field measurements.
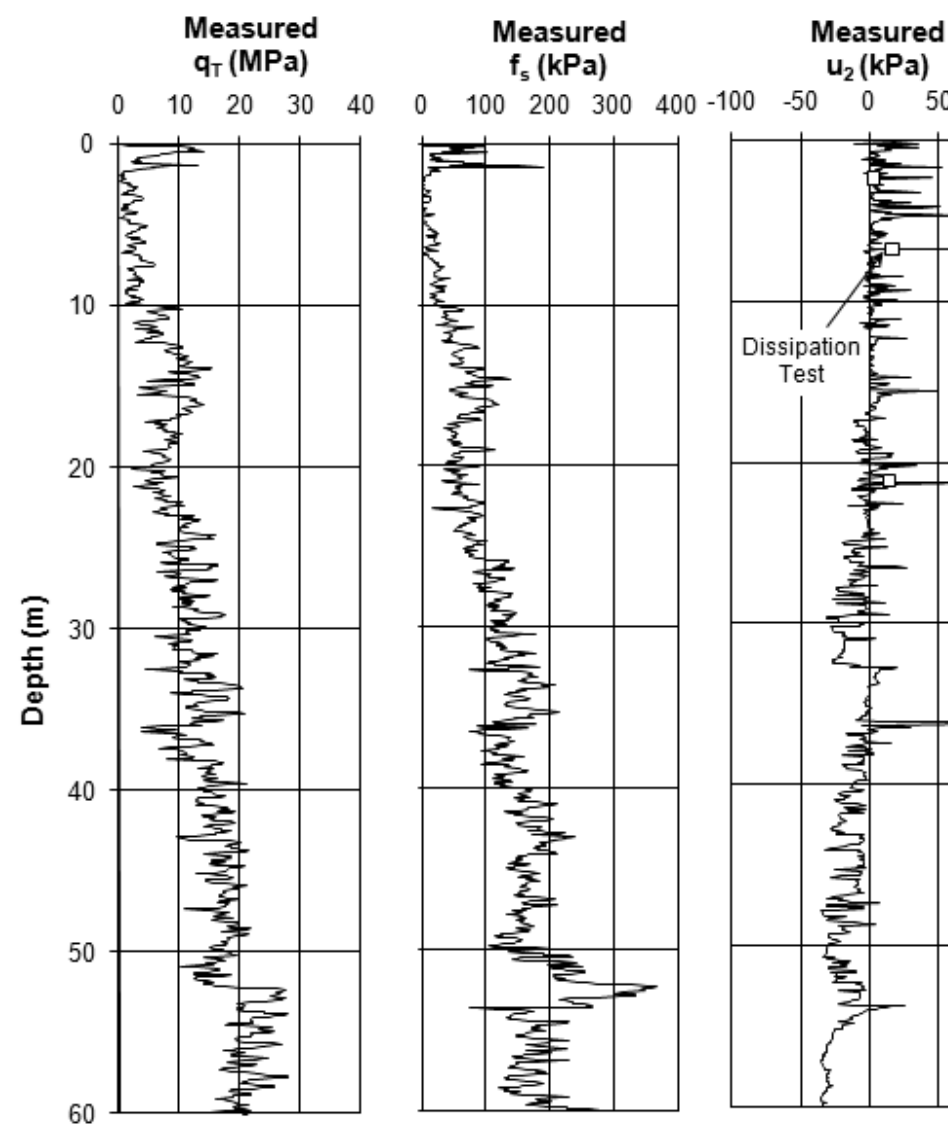

Correlated

SPT $\mathrm{N}_{60}$
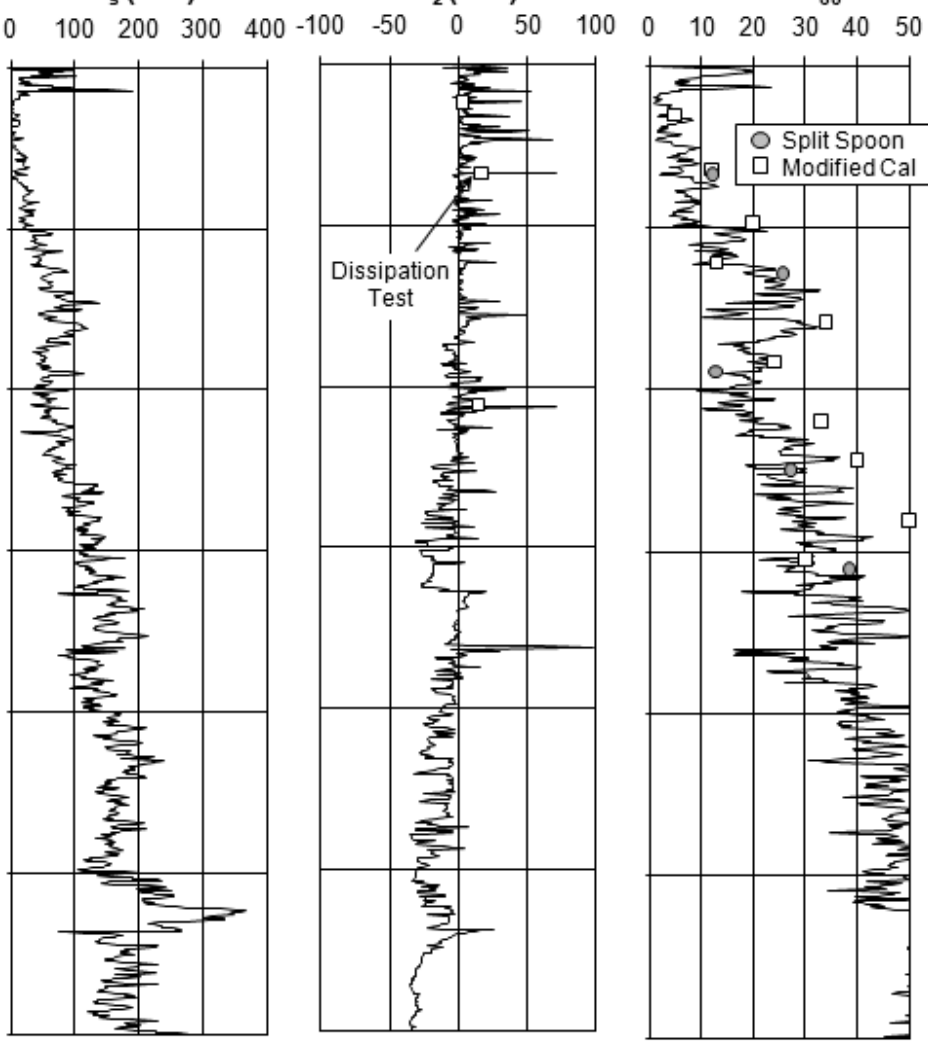

Figure 4 Cone penetration test sounding performed along proposed crest realignment, with comparison of correlated SPT $N_{60}$ to measured field values from paired drill hole

The CPT provides a number of advantages over the SPT for liquefaction assessments. Not only are CPTs are more economical to perform, but the standardised test procedure is more reproducible than the SPT, and the CPT provides a continuous record of penetration resistance throughout the soil deposit, which allows a better 
description of soil variability including identification of thin liquefiable sand or silt seams (Stark and Olson, 1995). For these reasons, it was preferred to develop a relationship between the CPT tip resistance and liquefaction potential rather than relying on a conversion from the SPT blow count.

The CPT soundings and laboratory test results performed along the proposed crest realignment centreline show that the tailings materials in this vicinity are typically silty sand or sandy silt with occasional thin $(<8 \mathrm{~mm})$ silt lenses. Occasional nearly saturated perched zones were encountered within the proposed crest realignment area; however, the majority of the materials encountered were unsaturated as demonstrated by the pore pressure measurements $\left(u_{2}\right)$ presented in Figure 4. Tailings management during the winter months involves deposition of whole tailings in the proposed crest realignment area; a practice which is planned to continue until realignment of the dam crest occurs when the currently permitted dam height is reached.

\subsection{Pore pressure dissipation testing}

The penetrometer used for the CPT testing was equipped with a pore pressure transducer at the type 2 (shoulder) position (i.e. $u_{2}$ ), allowing for pore pressures to be measured continuously during advancement of the cone. When the pore pressure transducer encountered zones of measurable pore pressure, the cone advancement was stopped while the time for dissipation of excess pore water pressures was measured (termed dissipation testing). Dissipation tests were performed until equilibrium values were reached. Figure 5 graphically presents several typical pore pressure dissipation results from the field programme at TCM.

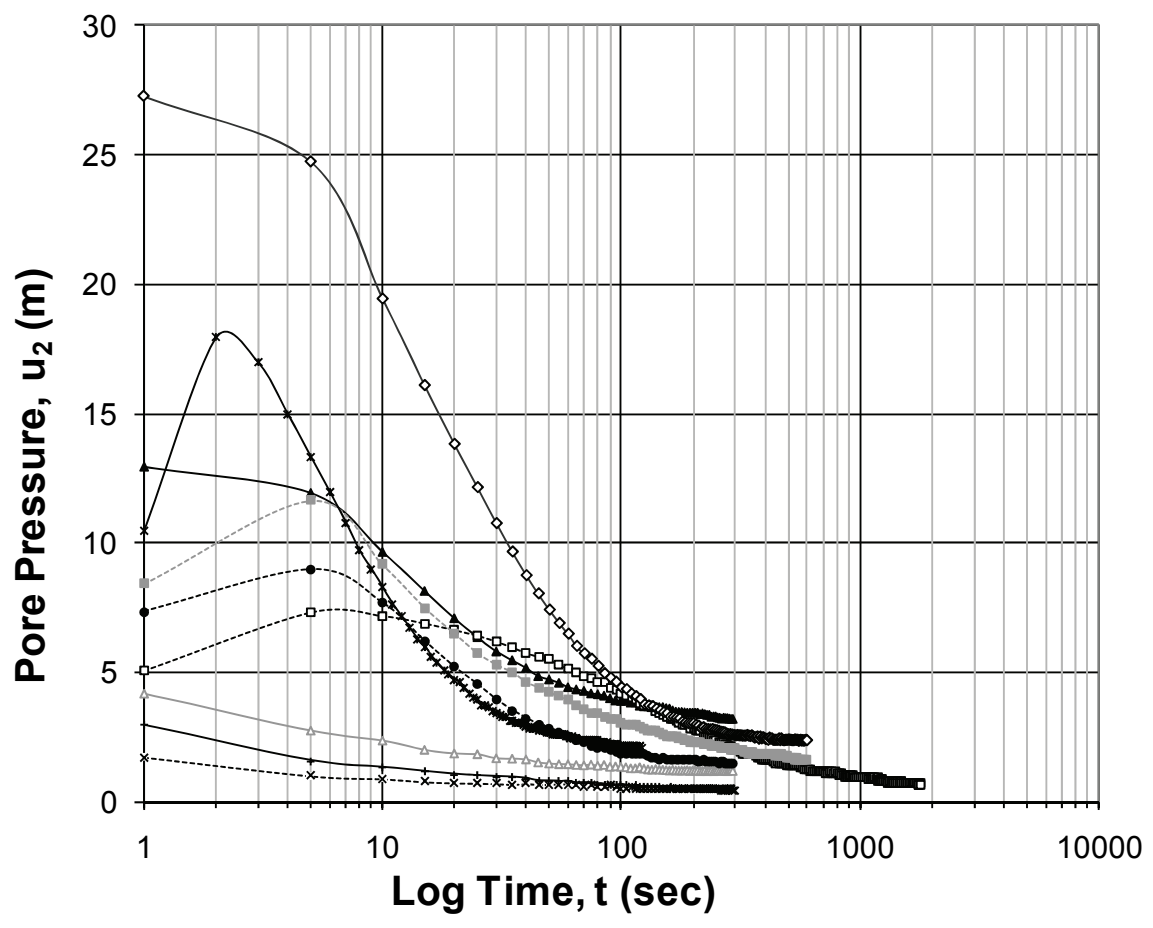

Figure 5 Dissipation test measurements recorded during CPT soundings

As shown in Figure 5, the excess pore pressures in the tailings required between five and 30 minutes to reach complete dissipation (i.e. $t_{100}$ ). Pore pressure dissipation testing was performed to provide estimates of the horizontal coefficient of consolidation $\left(c_{h}\right)$, in situ horizontal permeability $\left(k_{h}\right)$, and in situ pore water pressure conditions in the tailings. Though it is not customary to perform dissipation tests in unsaturated soils, results of the field dissipation test interpretations compared well with laboratory test results (e.g. consolidation tests, permeability tests) validating use of the results obtained in the partially-saturated zones. 


\section{Dynamic liquefaction assessment}

Soil liquefaction is a major concern for structures constructed with or on saturated sandy soils (Robertson, 2010). Liquefaction generally occurs most often in saturated, loose to moderately dense granular soils with poor drainage, such as silty sands, clean sands or gravels (Youd et al., 2001; NRC, 1985). Reduction of the soil saturation ratio to about 90 percent has been shown to increase the liquefaction resistance of soils by approximately two times that of fully saturated samples (Tsukamoto et al., 2002). The consequence of liquefaction can include global instability or flow failures, ground loss, settlement, localised differential movements, etc.

The distinction between liquefaction due to cyclic loading, where the effective overburden stress can reach zero during cyclic loading with a resulting loss of soil stiffness (cyclic liquefaction), and liquefaction due to strain softening with a resulting loss of shear strength (flow liquefaction), was made by Robertson and Wride (1998). Flow liquefaction is also commonly referred to as static liquefaction (e.g. Jeffries and Been, 2006; Robertson, 2010). As a result of the selected construction method (i.e. cyclone sand dam) for the Bruno Creek Tailings Impoundment, a relatively low density (i.e. uncompacted) material forms the outer walls of the dam. This material could be susceptible to static liquefaction (Ulrich and Fourie, 2003). However, this paper focuses on cyclic (or dynamic) liquefaction of the proposed crest realignment resulting from the site seismicity.

Cyclic liquefaction is the reduction in shear strength when the pore pressure builds up to the overburden pressure reducing the effective stress to zero. During a seismic event, an increase in pore pressure occurs when the soil is subjected to cyclic shear stresses induced by the cycles of ground motions.

\subsection{Ground motions for liquefaction analyses}

The ground motions for the OBE and MCE were developed for a weak rock site $\left(V_{S}=760 \mathrm{~m} / \mathrm{s}\right)$. Simplified liquefaction assessments require an estimate of the peak acceleration at the crest of the dam. The ground motions may be amplified (or de-amplified) as they propagate up through the tailings dam. Stronger ground motions induce larger shear strains, which result in higher material damping in the soils.

The simplified method of Bray et al. (1998) was used to develop an estimate of the peak horizontal accelerations at the crest of the ultimate dam for the post-closure conditions. Based on this method, damping occurs resulting in peak horizontal accelerations at the dam crest ranging from 0.22 to $0.29 \mathrm{~g}$, nominally less than the design seismic acceleration of $0.3 \mathrm{~g}$. For conservatism in the analyses, a PGA of $0.3 \mathrm{~g}$ was used in the cyclic liquefaction assessment.

\subsection{Phreatic conditions}

Field and laboratory test results combined with piezometric monitoring performed within the tailings impoundment show that both the tailings dam as well as the proposed crest realignment area are partially saturated. The current phreatic levels within the tailings dam are assumed to be representative of the phreatic conditions at the ultimate configuration, which was confirmed via seepage modelling.

Though groundwater was not encountered within the tailings dam and proposed partial realignment area (i.e. beach) during the field programme, the liquefaction potential of the existing tailings dam and proposed partial realignment area was evaluated conservatively assuming the groundwater coincides with the ground surface (saturated conditions), as well as the expected situation with groundwater below the investigated depth of $60 \mathrm{~m}$ (unsaturated conditions). Performing the liquefaction evaluation with a deep groundwater table implicitly assumes that the percent saturation in the soils is sufficient for liquefaction. This is likely conservative as it has been shown that a slight decrease in percent saturation (to 90 percent) results in a doubling of the liquefaction resistance of the soils (Tsukamoto et al., 2002). However, lowering the groundwater table will result in an increase in the effective stress in the soils, thereby increasing their resistance to liquefaction.

It should be noted that the assumption that groundwater is located at the ground surface is highly conservative, given the tailings deposition methods, high permeability of the tailings dam and tailings beach area, slow rate of rise of the tailings dam above the beach area, and the high degree of underdrainage anticipated (and demonstrated via groundwater monitoring). 


\subsection{Methodology}

The dynamic liquefaction potential of the foundation for the proposed partial crest realignment centreline was evaluated under existing and simulated future loading conditions for both the OBE and MDE events using data from the CPT soundings. The methodology (NCEER, 1997) requires an estimate of the cyclic stress ratio (CSR) profile caused by the design earthquake (i.e. load that the soil deposit will be subjected to as a result of the earthquake), then comparing that to the cyclic resistance ratio $(C R R)$ of the soil (i.e. the resistance of the soil to liquefaction). If the $C S R$ is greater than the $C R R$, cyclic liquefaction may occur.

A site-specific seismicity analysis may be carried out to evaluate the CSR profile with depth. However, a simplified method (NCEER, 1997), presented in Equation (1), was used to develop the CSR profile for the TCM tailings.

$$
C S R=0.65\left(a_{\max } / g\right) \times\left(\sigma_{v o} / \sigma_{v o}^{\prime}\right) \times r_{d}
$$

In Equation (1), $a_{\max }$ is the maximum horizontal ground surface acceleration at the site, $g$ is the acceleration due to gravity, $\sigma_{v o}$ and $\sigma_{v o}^{\prime}$ are the total and effective overburden stresses, respectively, and $r_{d}$ is a stress reduction factor that is dependent on depth. For the future ultimate loading configuration evaluation, the CSR values of the beach tailings were adjusted based on future overburden stress conditions assuming full saturation of the soil column above. It should be further noted that the analyses conservatively assumed no improvement of the existing tailings beach materials under the future loading.

Due to the continuous, reliable, and repeatable nature of CPT data, the CPT has become popular for evaluation of the CRR (NCEER, 1997). The CRR for a magnitude 7.5 earthquake is evaluated from the following equations:

$$
\begin{gathered}
C R R_{7.5}=93 \cdot\left(\frac{\left(q_{c 1 N}\right)_{c s}}{1000}\right)^{3}+0.08 \text { if } 50 \leq\left(q_{c 1 N}\right)_{c s} \leq 160 \\
C R R_{7.5}=0.833 \cdot\left(\frac{\left(q_{c 1 N}\right)_{c s}}{1000}\right)^{3}+0.05 \text { if }\left(q_{c 1 N}\right)_{c s} \leq 50
\end{gathered}
$$

Where $\left(q_{c I N}\right)_{c s}$ is an equivalent clean sand cone penetration resistance (Robertson and Wride, 1998). For simplicity, evaluation of the $\left(q_{c l N}\right)_{c s}$ profile is not discussed further herein; however, the value is a function of the grain characteristics of the soil.

The factor of safety of the soil against liquefaction is then evaluated from the $C R R_{7.5}$ and the $C S R$ using Equation (4).

$$
F S_{\text {Liquefaction }}=\left(\frac{C R R_{7.5}}{C S R}\right) \cdot M S F \cdot K_{\sigma}
$$

In Equation (4), $M S F$ is the Magnitude Scaling Factor to convert $C R R_{7.5}$ for an earthquake with $\mathrm{M} 7.5$ to the equivalent $C R R$ for the design earthquake (NCEER, 1997). As discussed above, the design earthquake at the TCM tailings site is M 5.8 and M 6.5 for operations and post-closure conditions, respectively. The variable $K_{\sigma}$ is a correction factor for high effective overburden stresses.

\subsection{Results}

Profiles of the factor of safety against liquefaction under existing conditions were developed for each of the CPT soundings conducted along the proposed crest realignment under operations and post-closure conditions. Figure 6 shows the factor of safety against liquefaction versus depth of the existing tailings beach for all five of the CPT soundings performed along the proposed crest realignment centreline assuming groundwater at the ground surface (saturated conditions). Figure 7 shows the factor of safety against liquefaction versus depth of the existing tailings beach for all five of the CPT soundings performed along the proposed crest realignment centreline assuming a deep $(>60 \mathrm{~m})$ groundwater surface (unsaturated conditions). 

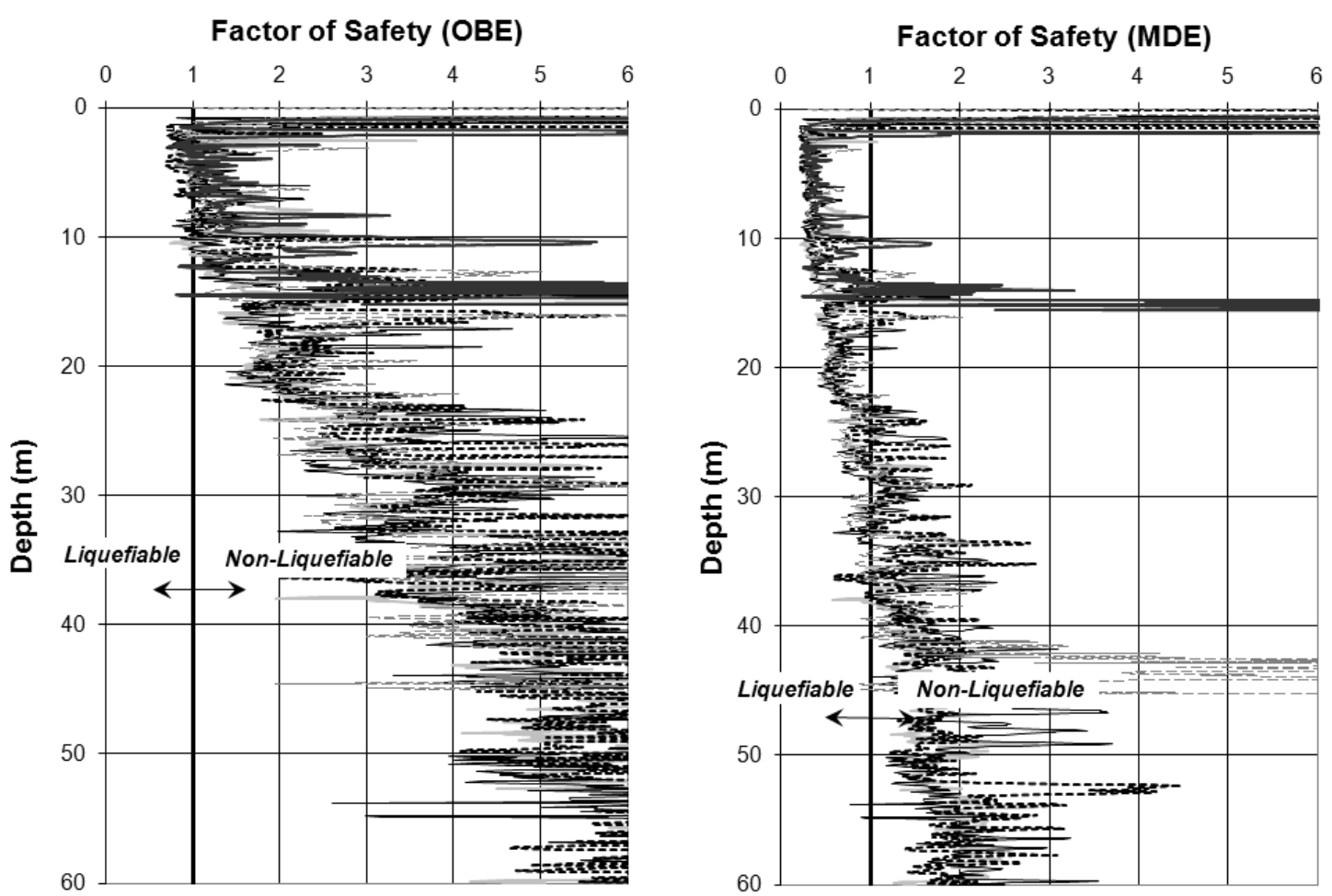

Figure 6 Factor of safety against liquefaction (assuming saturated conditions) under OBE (left) and MDE (right) for the proposed crest realignment area (results from five CPT soundings)
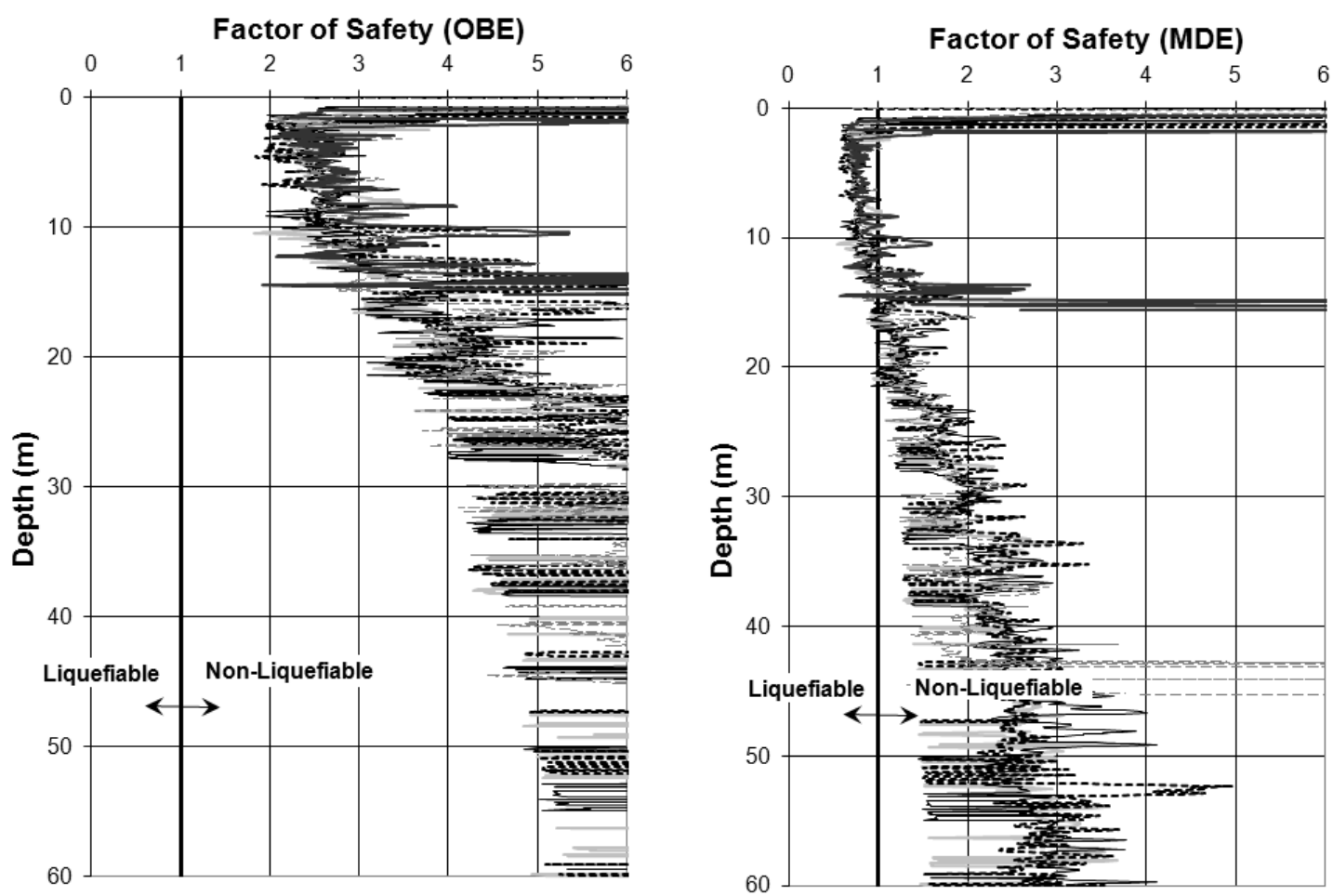

Figure 7 Factor of safety against liquefaction (unsaturated conditions) under OBE (left) and MDE (right) for the proposed crest realignment area (results from five CPT soundings)

The existing beach tailings present along the proposed dam crest realignment centreline were evaluated for liquefaction under the overburden pressure from the ultimate tailings dam, as presented in Figure 8 . The tailings were assumed to be the same as those present immediately prior to the crest realignment 
construction. Further, the tailings were conservatively assumed to exhibit no improvement from the future loading.
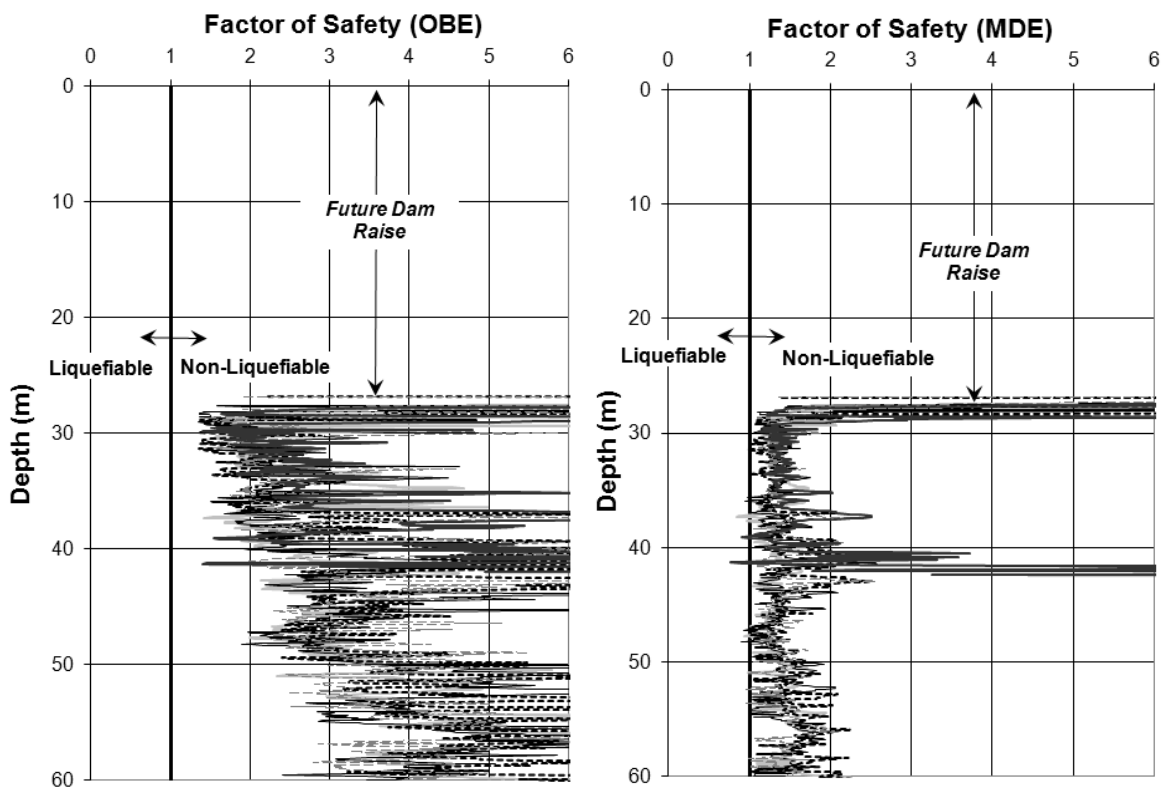

Figure 8 Factor of safety against liquefaction (assuming saturated conditions) exposed to loading from future dam raise under OBE (left) and MDE (right) for the proposed crest realignment area (results from five CPT soundings)

Figures 6 through 8 indicate that the tailings beach area beneath the proposed crest realignment centreline generally has a low potential for liquefaction during the OBE. The upper approximately $40 \mathrm{~m}$ of the tailings beach above which the crest realignment centreline will be constructed is potentially liquefiable under the MDE event, conservatively assuming that these materials are saturated (Figure 6). Figure 7 shows that lowering the groundwater surface reduces the liquefaction potential within the tailings beach.

Assuming fully-saturated conditions (i.e. phreatic surface at the ultimate LOM tailings surface), the factor of safety against liquefaction for the tailings beach materials under future ultimate loading conditions along the centreline of the proposed crest realignment is greater than one, indicating that the tailings beach materials are non-liquefiable (refer to Figure 8). This analysis is likely conservative as the CPT measurements made under the current overburden conditions were not adjusted upward to account for densification under future dam loading over the beach.

\section{Conclusions}

The Bruno Creek Tailings Impoundment, located in seismically-active central Idaho (USA), retains tailings behind one of the tallest centreline-raise cyclone tailings sand dams in the world. From a current height of approximately $170 \mathrm{~m}$, the dam is proposed to be raised to a height of nearly $230 \mathrm{~m}$ by constructing a partial realignment of the dam crest over tailings beach materials.

The tailings embankment will continue to be constructed with cycloned sand tailings using the centreline raise method. However, the left abutment (northeast) portion of the dam centreline will be angled upstream, placing this portion of the new embankment centreline over the tailings beach. This centreline shift will not occur until the currently permitted height of the dam is reached. During the following phase, the embankment is designed to have a steeper downstream slope of $2.75 \mathrm{H}: 1 \mathrm{~V}$ (from the current $3 \mathrm{H}: 1 \mathrm{~V}$ ), with other embankment geometries (crest width, beach slope, etc.) remaining the same as the current design. Part of the downstream face below the realigned portion of the dam will toe out on the tailings beach, and a minimum 5 percent downstream slope will be maintained to encourage drainage of the area.

A field and laboratory testing programme was performed to design the tailings impoundment expansion, which included assessment of the dynamic liquefaction potential of the existing dam and proposed partial 
crest realignment centreline (i.e. tailings beach materials). The liquefaction assessment, using the methodology presented in NCEER (1997) with CPT data, shows that the tailings beach beneath the proposed crest realignment centreline has a low potential for liquefaction under the seismic loading conditions evaluated in this study, primarily because the tailings are not fully saturated, nor are they expected to become fully saturated under normal operating conditions. However, if groundwater is conservatively assumed to be located at the ground surface, the upper approximately 20 to $40 \mathrm{~m}$ of the tailings beach is potentially liquefiable under the MDE event, but not under the OBE event.

TCM maintains an active monitoring system to monitor real-time phreatic conditions within the tailings dam, which includes extension of piezometers as the dam is raised, replacement of piezometers as they become damaged, and installation of new piezometers, as needed. Historical monitoring shows that the dam is welldrained, with the phreatic surface present at the base of the dam (in constructed drains). During construction of the partial crest realignment, additional piezometers will be installed in the tailings beach along the realignment centreline to monitor water levels in this area.

\section{Acknowledgements}

The authors would like to thank Thompson Creek Metals Company for allowing this paper to be published, and for the combined efforts of the project team in advancing the facility design.

\section{References}

Bray, J.D., Rathje, E.M., Augello, A.J. and Merry, S.M. (1998) Simplified Seismic Design Procedure for Lined SolidWaste Landfills, Geosynthetics International Journal, No. 1.

Idaho Administrative Code (IAC) (2010a) Safety of Dams Rules, IDAPA 37 Title 03 Chapter 06 (37.03.06).

Idaho Administrative Code (IAC) (2010b) Mines Tailings Impoundment Structures Rules, IDAPA 37 Title 03 Chapter 05 (37.03.05).

International Committee on Large Dams (ICOLD) (2002) Seismic Design and Evaluation of Structures Appurtenant to Dams, Guidelines, Bulletin 123.

Jeffries, M.G. and Been, K. (2006) Soil Liquefaction - A Critical State Approach, Taylor and Francis, London.

Jeffries, M.G. and Davies, M.P. (1993) Use of CPT Values to Estimate Equivalent SPT N60, ASTM Geotechnical Testing J., Vol. 16, No. 4, pp. 458-467.

NCEER (1997) Contributions from Youd, T.L., Idriss, I.M., Andrus, R.D., Arango, I., Castro, G., Christian, J.T., Dobry, R., Finn, W.D.L., Harder, L.F., Hynes, M.E., Ishihara, K., Koester, J., Liao, S., Marcuson III, W.F., Martin, G.R., Mitchell, J.K., Moriwaki, Y., Power, M.S., Robertson, P.K., Seed, R. and Stokoe, K.H., Summary Report of the 1996 NCEER Workshop on Evaluation of Liquefaction Resistance, Salt Lake City, Utah.

NRC (1985) Liquefaction of Soils During Earthquakes, National Academy Press, Washington D.C.

Richins, W., Pechman, J., Smith, R., Langer, C., Goter, S., Zollweg, J. and King, J. (1987) The 1983 Borah Peak, Idaho, earthquake and aftershocks, Bulletin of the Geological Society of America, Vol. 77, pp. 694-723.

Robertson, P.K. (2010) Evaluation of Flow Liquefaction and Liquefied Shear Strength Using the Cone Penetration Test, J. Geotechnical and Geoenvironmental Engineering, Vol. 136, No. 6, ASCE, pp. 842-853.

Robertson, P.K. and Wride, C.E. (1998) Evaluating Cyclic Liquefaction Potential Using the CPT, Canadian Geotechnical Journal, Vol. 35, No. 3, pp. 442-459.

SRK (1995) Embankment Seepage and Stability Issues, Technical memorandum from R. Dorey to B. Doughty (TCMC).

Stark, T.D. and Olson, S.M. (1995) Liquefaction Resistance Using CPT and Field Case Histories, Journal of Geotechnical Engineering, Vol. 121, No. 12, ASCE, pp. 856-869.

Tsukamoto, Y., Ishihara, K., Nakazawa, H., Kamada, K. and Huang, Y. (2002) Resistance of Partially Saturated Sand to Liquefaction with Reference to Longitudinal and Shear Wave Velocities, Soils and Foundations, Vol. 42, No. 6, pp. 93-104.

Ulrich, B.F. and Fourie, A.B. (2003) Assessment of the potential for static liquefaction of a tailings dam using laboratory and field testing, Tailings and Mine Waste '03, in Proceedings Tenth International Conference on Tailings and Mine Waste, 12-15 October 2003, Vail, Colorado, USA, A.A. Balkema Publishers.

Youd, T.L., Idriss, I.M., Andrus, R.D., Arango, I., Castro, G., Christian, J.T., Dobry, R., Liam Finn, W.D., Harder Jr., L.F., Hynes, M.E., Ishihara, K., Koester, J.P., Liao, S.S.C., Marcuson III, W.F., Martin, G.R., Mitchell, J.K., Moriwaki, Y., Power, M.S., Robertson, P.K., Seed, R.B. and Stokoe II, K.H. (2001) Liquefaction Resistance of Soils: Summary Report from the 1996 NCEER and 1998 NCEER/NSF Workshops on Evaluation of Liquefaction Resistance of Soils, Journal fo Geotechnical and Geoenvironmental Engineering, Vol. 127, No. 10, ASCE. 
